\title{
Comparing floristic composition in treefall gaps of certified, conventionally managed and natural forests of northern Honduras
}

\author{
Mari KUKKONEN*, Stefan HOHNWALD \\ Department of Biological and Environmental Sciences, P.O. Box 27, 00014, University of Helsinki, Finland
}

(Received 8 July 2008; revised version 16 January 2009; accepted 27 May 2009)

Keywords:

floristic composition /

forest certification /

logging gap /

Honduras /

reduced-impact logging

\begin{abstract}
- Forest certification sets requirements for minimizing the impacts of logging on the natural structure and floristic composition of forests.

- We assessed the impact of certification by comparing the floristic composition of 52 taxa of trees and shrubs in the treefall gaps of certified, conventionally managed and protected forests in northern Honduras.

- The highest abundance of light-benefiting taxa was found in certified forests, whereas conventionally managed forests were floristically more similar to natural forests. The environmental conditions measured in certified gaps were not favourable for a natural forest floristic composition.

- Past logging may have altered the species composition in certified forests relatively more than in conventionally managed forests. This implies that the need for restoration operations should be considered in certification requirements, along with landscape-level planning to enhance post-logging recovery.
\end{abstract}

Résumé - Comparaison de la composition floristique dans les trouées d'abattage d'arbres dans les forêts certifiées, conventionnellement gérées et naturelles du Nord du Honduras.

- La certification forestière définit des exigences pour minimiser les impacts de l'exploitation forestière sur la structure naturelle et la composition floristique des forêts.

- Nous avons évalué l'impact de la certification, en comparant la composition floristique de 52 taxons d'arbres et d'arbustes dans les trouées d'abattage d'arbres de forêts certifiées, conventionnellement gérées et protégées du Nord du Honduras.

- La plus grande abondance des taxons profitant de la lumière a été trouvée dans les forêts certifiées, alors que les forêts gérées de façon conventionnelle ont été floristiquement plus proches des forêts naturelles. Les conditions environnementales mesurées dans les trouées certifiées n'étaient pas favorables à une composition floristique de forêt naturelle.

- L'exploitation forestière passée, peut avoir modifié la composition des espèces dans les forêts certifiées relativement plus que dans les forêts gérées. Cela implique que le besoin d'opérations de restauration doit être pris en compte dans les exigences de certification.

\begin{abstract}
Abbreviations: FSC - Forest Stewardship Council; CeF - Certified forest; CoM - Conventionally managed forest; NaF - Natural (protected) forest; RIL - Reduced-impact logging; MN Management-neutral; MS - Management-sensitive.
\end{abstract}

\section{INTRODUCTION}

In recent years, environmental certification has been promoted as a way to achieve sustainable forest management. Nevertheless, only a few percent of tropical forests have been certified (UNECE/FAO, 2008), and few studies have examined the ecological impacts of certification on tropical

*Corresponding author: mari.kukkonen@helsinki.fi systems. The main certifier of tropical forests is the Forest Stewardship Council (FSC) (van Kooten et al., 2005). The FSC requires that certified management fulfils certain ecological, social and economic criteria (FSC, 2004). In selectively logged tropical forests, the aims of ecologically sustainable forest management include maintenance of the natural forest $(\mathrm{NaF})$ structure, biodiversity and ecological processes. In practice, the requirements for certified management mainly consist of implementing pre-harvest planning and reduced-impact 


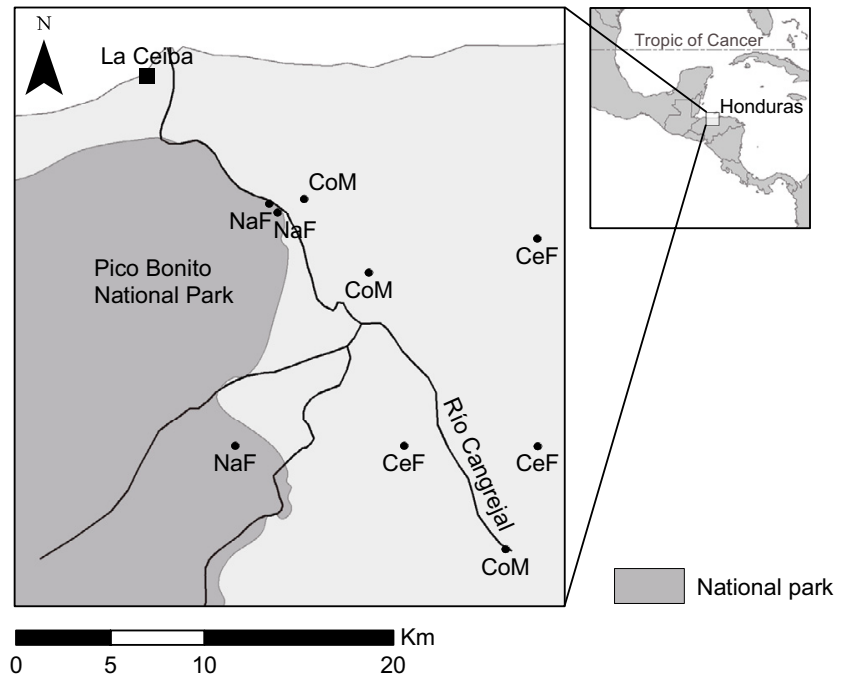

Figure 1. Location of sampled certified $(\mathrm{CeF})$, natural $(\mathrm{NaF})$ and conventionally managed $(\mathrm{CoM})$ forests in relation to the city of La Ceiba $\left(15^{\circ} 38^{\prime} \mathrm{N}, 86^{\circ} 40^{\prime} \mathrm{W}\right)$.

logging (RIL) techniques, along with the protection of vulnerable species and ecosystems.

Studies comparing RIL with conventional logging practices show that the use of RIL practices may effectively limit the negative impacts of selective logging on forest structure and composition (Sist et al., 2003). Controlling harvesting intensity helps to prevent a decrease in the abundance of valuable timber species (Sist et al., 1998), and limiting mechanical logging damage prevents damage to trees in residual stands (Chapman and Chapman, 1997). At the forest level, these activities reduce ground-level disturbance (Uhl and Vieira, 1989) and the opening of the canopy cover (Pereira et al., 2002), helping to control the increase in the relative abundance of light-benefiting pioneer species (Primack and Lee, 1991).

We examined the ecological impact of certified forest $(\mathrm{CeF})$ management by comparing $\mathrm{CeFs}$ with protected $\mathrm{NaFs}$ and conventionally managed forests (CoMs). Two expectations were defined to evaluate the impact of $\mathrm{CeF}$ management at the level of a single treefall gap. First, due to improvements related to limiting harvest intensity and mechanical logging damage in $\mathrm{CeFs}$, we expected the floristic composition to be more similar between $\mathrm{CeF}$ and $\mathrm{NaF}$ gaps than between $\mathrm{CoM}$ and $\mathrm{NaF}$ gaps. Second, we expected that certified management practices would better mimic the natural disturbance regime, thus creating gap conditions that support a floristic composition similar to that of a natural forest.

\section{MATERIAL AND METHODS}

\subsection{Study sites}

The studied forests are situated in the Río Cangrejal watershed in northern Honduras (Fig. 1). They are classified as tropical moist and premontane wet forests (Holdridge, 1967). Typical tree species include Euterpe precatoria Mart. (Arecaceae), Vochysia spp. Aubl (Vochysiaceae) (Salazar, 2000), Genipa americana L. (Rubiaceae) and Terminalia amazonia (J.F. Gmel.) Exell (Combretaceae) (Ferrando, 1998). A description of the climatic conditions of the area can be found in Kukkonen et al. (2008).

Uncontrolled selective loggings in Río Cangrejal began on a major scale in the 1970s. Early loggings focused on a few valuable species, including Swietenia macrophylla King (Meliaceae) and Cedrela odorata L. (Meliaceae) (Markopoulos, 1999). After these species became rare, the range of marketed timbers expanded, and currently covers about 20 species.

The CeFs and CoMs studied are owned by the state and managed by local community forest groups under a usufruct agreement. Each forest group harvests a segment of 10 to 20 ha of forest each year, with annual logging intensities between 2.2 and 6.5 trees per ha. The rotation period is 30 years. The NaFs studied were located in Pico Bonito National Park, which borders the managed forests in the Río Cangrejal watershed. Our sample sites were situated in areas of restricted human intervention.

\subsection{Sampling}

We selected three replicate forests within each management type (CeF, CoM and $\mathrm{NaF}$ ) (Tab. I). Five logging gaps were sampled in each $\mathrm{CeF}$ and $\mathrm{CoM}$ and five natural treefall gaps in each $\mathrm{NaF}$ (apart from Pico Bonito, where six treefall gaps were sampled). Within each of the 46 treefall gaps, we sampled three round $100-\mathrm{m}^{2}$ plots, situated in the stump, bole and canopy sites where the tree had fallen. The stump site was situated to exclude the tree stump itself and possible sprouts. The bole site was situated in the centre of the trunk of the fallen tree, and the canopy site was situated in the middle of the crown. At each site, we recorded all woody plants $\geq 1 \mathrm{~cm}$ in dbh (diameterat-breast height). Samples were identified to species, or when this was impossible, to the genus level. Two species (Persea schiedeana Nees and Conostegia xalapensis (Bonpl.) D. Don ex DC.) with fewer than 10 recorded individuals were removed from the dataset. The final dataset thus consisted of 52 tree and shrub taxa (Tab. II).

We also recorded a total of 15 environmental variables in the sampled gaps. For the analyses, these were divided into two subgroups (cf. Kukkonen et al., 2008): management-neutral (MN) and management-sensitive (MS) gap characteristics (Tab. A, available online at www.afs-journal.org). The MN gap characteristics were expected to be neutral with regard to management type, whereas the variables included in the MS subgroup were expected to be sensitive to differences in management type. Stem density was included in the MS gap characteristics, because reduced damage in $\mathrm{CeF}$ management may increase the density of surviving advance regeneration (Jackson et al., 2002). The abundance of lianas (Schnitzer and Bongers, 2002), herbs (Cusack and Montagnini, 2004) and shrubs (Denslow et al., 1990) has been shown to decrease with reduced mechanical logging damage. The abundance of trees and the coverage of litter may be positively affected by reduced disturbance (Dickinson et al., 2000).

\subsection{Data analyses}

We used constrained ordination to study the variation in floristic data between management types (CeF, $\mathrm{CoM}$ and $\mathrm{NaF})$. A preliminary 
Table I. Description of the studied forests.

\begin{tabular}{|c|c|c|c|c|c|c|}
\hline Forest & $\begin{array}{l}\text { Geographic coordinates } \\
\text { (in decimal degrees) }\end{array}$ & $\begin{array}{l}\text { Size of production } \\
\text { forest (ha) }\end{array}$ & $\begin{array}{l}\text { Altitude } \\
\text { (m, a.s.1.) }\end{array}$ & $\begin{array}{l}\text { Total sapling density } \\
\text { in gaps (mean } \pm \mathrm{SD})\end{array}$ & $\begin{array}{c}\text { Gap age } \\
(\mathrm{y}, \text { mean } \pm \mathrm{SD})\end{array}$ & $\begin{array}{c}\text { Gap size } \\
\left(\mathrm{m}^{2}, \text { mean } \pm \mathrm{SD}\right)\end{array}$ \\
\hline CeF 1 (Río Viejo) & $15.60111,86.66722$ & 618 & 930 & $240 \pm 51$ & $8.0 \pm 0.0$ & $199 \pm 43$ \\
\hline CeF 2 (Toncontín) & $15.60083,86.60111$ & 1061 & 900 & $183 \pm 57$ & $2.8 \pm 0.8$ & $235 \pm 131$ \\
\hline CeF 3 (Yaruca) & $15.70028,86.60111$ & 625 & 650 & $171 \pm 43$ & $5.6 \pm 0.5$ & $170 \pm 33$ \\
\hline $\mathrm{CeF}$ (total mean) & - & 768 & 827 & $198 \pm 56$ & $5.5 \pm 2.3$ & $201 \pm 80$ \\
\hline CoM 1 (El Naranjo) & $15.71806,86.71722$ & 1682 & 250 & $186 \pm 81$ & $2.6 \pm 0.5$ & $259 \pm 76$ \\
\hline CoM 2 (El Pital) & $15.68417,86.68472$ & N/A & 500 & $206 \pm 29$ & $2.4 \pm 0.5$ & $293 \pm 112$ \\
\hline CoM 3 (El Urraco) & $15.55139,86.61722$ & 1709 & 950 & $69 \pm 43$ & $6.4 \pm 2.2$ & $252 \pm 61$ \\
\hline CoM (total mean) & - & 1331 & 567 & $154 \pm 81$ & $3.8 \pm 2.3$ & $268 \pm 82$ \\
\hline NaF 1 (Las Mangas) & $15.71694,86.71806$ & - & 850 & $178 \pm 69$ & $6.8 \pm 1.1$ & $269 \pm 191$ \\
\hline NaF 2 (La Primavera) & $15.60111,86.75083$ & - & 200 & $158 \pm 6$ & $7.2 \pm 0.4$ & $381 \pm 130$ \\
\hline NaF 3 (Pico Bonito) & $15.71722,86.73389$ & - & 200 & $163 \pm 19$ & $5.8 \pm 1.3$ & $251 \pm 160$ \\
\hline $\mathrm{NaF}$ (total mean) & - & - & 403 & $166 \pm 38$ & $6.6 \pm 1.2$ & $297 \pm 162$ \\
\hline
\end{tabular}

detrended canonical correspondence analysis (DCCA) was run to select between linear and unimodal ordination methods (after ter Braak and Šmilauer, 2002). We selected linear ordination based on the relatively low extent of species turnover along the DCCA axes (gradient length $<3$ ). The linear form of constrained ordination is redundancy analysis (RDA), in which the distances between sample scores correspond to Euclidean distances in ordination space. Preliminary RDA showed that when all measured environmental variables were used as explanatory variables, the first two ordination axes explained $48.6 \%$ of the variation in floristic data.

To extract the variation explained by the MN and MS gap characteristics from the floristic data matrix before studying the residual variation with respect to the variables of interest, we used partial redundancy analysis (pRDA). Two pRDAs were conducted to test the expectations. With the first pRDA, we tested whether the floristic similarity between the $\mathrm{CeF}$ and $\mathrm{NaF}$ gaps was higher than that between the CoM and NaF gaps. To eliminate initial differences in the MN gap characteristics (gap age, altitude, inclination, gap size, distance and percentage coverage of stones and deadwood), these were set as covariables (after Lepš and Šmilauer, 2003). The second pRDA was performed to assess the role of MS gap characteristics in explaining the differences in floristic similarity between the $\mathrm{CeF}$ and $\mathrm{NaF}$ gaps and the $\mathrm{CoM}$ and $\mathrm{NaF}$ gaps. This was performed by adding the MS gap characteristics (density and coverage of lianas, herbs, shrubs, litter, young and canopy trees) to the covariables together with the MN gap characteristics.

The pRDAs only accounted for that part of the variation that could be explained by the management type. To test the effect of management type in an unconstrained ordination space, i.e. to include all variation in floristic data, we conducted two principal component analysis (PCA) ordinations using the same sets of covariables. Differences in floristic composition among management types were tested by conducting analyses of variance (ANOVA) for the sample scores based on species composition on the first two axes in all ordinations. If significance was observed, the ANOVAs were followed by Dunnett's tests for pairwise comparisons between classes.

To conduct the pRDAs and PCAs we used the ecological ordination program CANOCO 4.5 (Plant Research International, Wageningen, the Netherlands) (ter Braak and Šmilauer, 2006). We selected centring by species and scaling focused on inter-sample distances. For the species data, a square-root transformation was conducted. All environmental variables were centred and standardized to zero mean and a variance of 1 (Lepš and Šmilauer, 2003). ANOVA and Dun- nett's tests were carried out using the statistical package SPSS (SPSS Inc., 2007).

\section{RESULTS}

\subsection{Floristic similarities}

According to the results, the floristic similarity between the $\mathrm{CeF}$ and $\mathrm{NaF}$ gaps was lower than that between the CoM and $\mathrm{NaF}$ gaps. The first pRDA (Fig. 2) showed that the Euclidean distance between the $\mathrm{CeF}$ and $\mathrm{NaF}$ gaps (0.40) was 1.5 times higher than that between the CoM and NaF gaps $(0.26)$. The MN variables explained $34.9 \%$ of the variation in floristic composition. With the MN variables set as covariables, this effect was factored out prior to the analysis. Management type explained $12.3 \%$ of the remaining variation, with the first constrained axis explaining $10.2 \%$ and the second $2.2 \%$ of the variation. The third and fourth unconstrained axes explained $10.2 \%$ and $7.8 \%$, respectively, indicating that there were significant environmental gradients not included in the analysis.

The effect of management type was statistically significant along the first, as well as the second axis sample scores (Tab. III). The Dunnett's tests revealed that the differences between the $\mathrm{CeF}$ and $\mathrm{NaF}$ gaps were statistically significant, whereas those between the CoM and NaF gaps were not (Tab. III). The PCA results confirmed that management type was a significant predictor of floristic composition. When the MN gap characteristics were set as covariables, the effect of management type was significant along the first axis (Tab. III). As in the pRDA, the Dunnett's tests showed that the differences between the $\mathrm{CeF}$ and $\mathrm{NaF}$ gaps were statistically significant, whereas those between the CoM and NaF gaps were not. Along the second axis, however, no similar trend was observed.

\subsection{Gap environmental conditions}

The results revealed that the gap conditions in the CeFs were not as favourable for a near-natural floristic composition as the gap conditions in the CoMs. When the effect of the 
Table II. List of taxa with family names and abbreviations used.

\begin{tabular}{|c|c|c|}
\hline Species/genus name & Family & Abbreviation \\
\hline Alchornea latifolia $\mathrm{Sw}$. & Euphorbiaceae & ALCLAT \\
\hline Billia hippocastanum Peyr. & Hippocastanaceae & BILHIP \\
\hline Brosimum alicastrum Sw. & Moraceae & BROALI \\
\hline Callicarpa acuminata Kunth & Verbenaceae & CALACU \\
\hline Calophyllum brasiliense Cambess. & Clusiaceae & CALBRA \\
\hline Calyptranthes chytraculia (L.) Sw. & Myrtaceae & CALCHY \\
\hline Carpotroche platyptera Pittier & Flacourtiaceae & CARPLA \\
\hline Cecropia peltata $\mathrm{L}$. & Cecropiaceae & CECPEL \\
\hline \multicolumn{3}{|l|}{ Cephaelis tomentosa (Aubl.) Vahl } \\
\hline (= Psychotria poeppigiana Müll. Arg.) & Rubiaceae & СЕРТОМ \\
\hline Cephaelis Sw. sp. (= Psychotria L. sp.) & Rubiaceae & CEPH_SP \\
\hline Cestrum racemosum Ruiz \& Pav. & Solanaceae & CESRAC \\
\hline Cojoba arborea (L.) Britton \& Rose & Fabaceae & COJARB \\
\hline Cordia alliodora (Ruiz \& Pav.) Oken & Boraginaceae & CORALL \\
\hline Cupania guatemalensis (Turcz.) Radlk. & Sapindaceae & CUPGUA \\
\hline Dendropanax arboreus (L.) Decne. \& Planch. & Araliaceae & DENARB \\
\hline Dialium guianense (Aubl.) Sandwith (= Arouna guianensis Aubl.) & Fabaceae & DIAGUI \\
\hline Dichapetalum bullatum Standl. \& Steyerm. & Dichapetalaceae & DICBUL \\
\hline Eugenia L. sp. & Myrtaceae & EUGE_SP \\
\hline Garcinia intermedia (Pittier) Hammel & Clusiaceae & GARINT \\
\hline Guarea grandifolia DC. & Meliaceae & GUAGRA \\
\hline Guarea macrophylla Vahl & Meliaceae & GUAMAC \\
\hline Hamelia patens Jacq. & Rubiaceae & HAMPAT \\
\hline Heliocarpus appendiculatus Turcz. & Tiliaceae & HELAPP \\
\hline Huertea cubensis Griseb. & Staphyleaceae & HUECUB \\
\hline Hyeronima alchorneoides Allemão & Euphorbiaceae & HYEALC \\
\hline Inga Mill. spp. & Fabaceae & INGA_SP \\
\hline Licania platypus (Hems1.) Fritsch & Chrysobalanaceae & LICAN_SP \\
\hline Licaria capitata (Schltdl. \& Cham.) Kosterm. & Lauraceae & LICCAP \\
\hline Licaria Aubl. spp. & Lauraceae & LICAR_SP \\
\hline Lonchocarpus guatemalensis Benth. & Fabaceae & LONGUA \\
\hline Matayba oppositifolia (A. Rich.) Britton & Sapindaceae & MATOPP \\
\hline Miconia Ruiz \& Pav. sp. & Melastomataceae & MICO_SP \\
\hline Mortoniodendron vestitum Lundell & Tiliaceae & MORVES \\
\hline Ochroma pyramidale (Cav. ex Lam.) Urb. & Bombacaceae & OCHPYR \\
\hline Pachira aquatica Aubl. & Bombacaceae & PACAQU \\
\hline Pausandra trianae (Müll. Arg.) Baill. & Euphorbiaceae & PAUTRI \\
\hline Pentagonia macrophylla Benth. & Rubiaceae & PENMAC \\
\hline Perymenium grande Hemsl. & Asteraceae & PERGRA \\
\hline Piper auritum Kunth & Piperaceae & PIPAUR \\
\hline Piper L. spp. & Piperaceae & PIPE_SP \\
\hline Piper umbellatum L. & Piperaceae & PIPUMB \\
\hline Pterocarpus rohrii Vahl & Fabaceae & PTEROH \\
\hline Rinorea hummelii Sprague & Violaceae & RINHUM \\
\hline Schizolobium parahyba (Vell.) S.F. Blake & Fabaceae & SCHPAR \\
\hline Simarouba glauca DC. & Simaroubaceae & SIMGLA \\
\hline Terminalia amazonia (J.F. Gmel.) Exell & Combretaceae & TERAMA \\
\hline Trema micrantha (L.) Blume & Ulmaceae & TREMIC \\
\hline Trichospermum sp. Blume & Tiliaceae & TRIC_SP \\
\hline Virola koschnyi Warb. & Myristicaceae & VIRKOS \\
\hline Vismia guianensis (Aubl.) Pers. & Clusiaceae & VISGUI \\
\hline Vismia baccifera (L.) Triana \& Planch. & Clusiaceae & VISBAC \\
\hline Xylopia frutescens Aubl. & Annonaceae & XYLFRU \\
\hline Total & & 52 \\
\hline
\end{tabular}




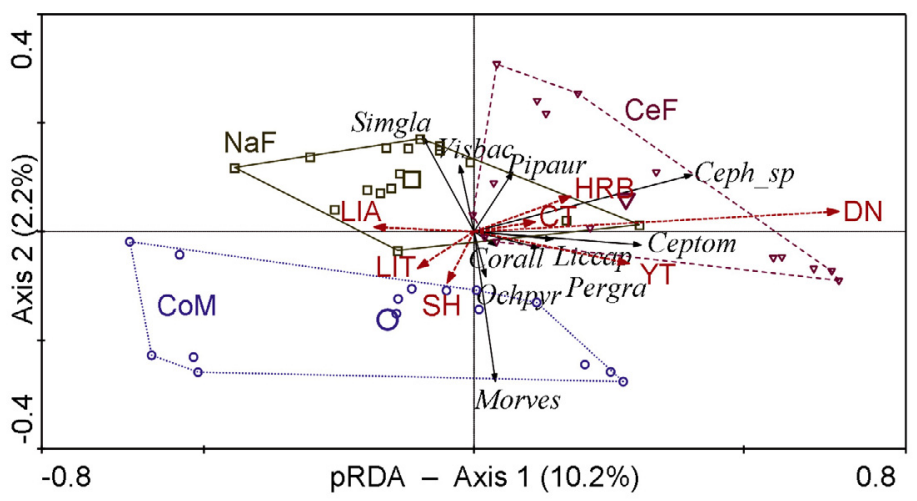

Figure 2. Partial redundancy analysis (pRDA) ordination diagram, plotting sample (gap) scores (small symbols) and class centroids of forest management types (large symbols) along with 10 taxa having the best fit. Distances between sample scores and between centroids correspond to Euclidean distances. Envelopes are drawn around samples of each management type, with sample scores represented as symbols $(\mathrm{CeF}=\mathrm{down}$ triangle, $\mathrm{CoM}=$ circle, $\mathrm{NaF}=$ square $)$. Arrows representing taxa point in the direction of increasing abundance. Axes 1 and 2 are constrained: management type is used as the explanatory variable. The percentage of variance in the floristic dataset (52 taxa) explained by each axis is indicated in brackets. Management-neutral (MN) gap characteristics are used as covariables. Management-sensitive (MS) gap characteristics are supplementary variables added to the ordination post hoc by regressing their data onto the ordination axes. Abbreviations for MS gap characteristics are as follows: $\mathrm{DN}=$ density, $\mathrm{HRB}=$ herb coverage, $\mathrm{SH}=$ shrub coverage, $\mathrm{LIT}=$ litter coverage, $\mathrm{LIA}=$ liana coverage, $\mathrm{CT}=$ coverage of canopy trees, $\mathrm{YT}=$ coverage of young trees.

Table III. Results of testing the significance of forest management type on the sample scores that are based on floristic composition. Sample scores are derived from constrained linear ordination (pRDA) and unconstrained linear ordination (PCA). $P-$ values below 0.05 are given in bold.

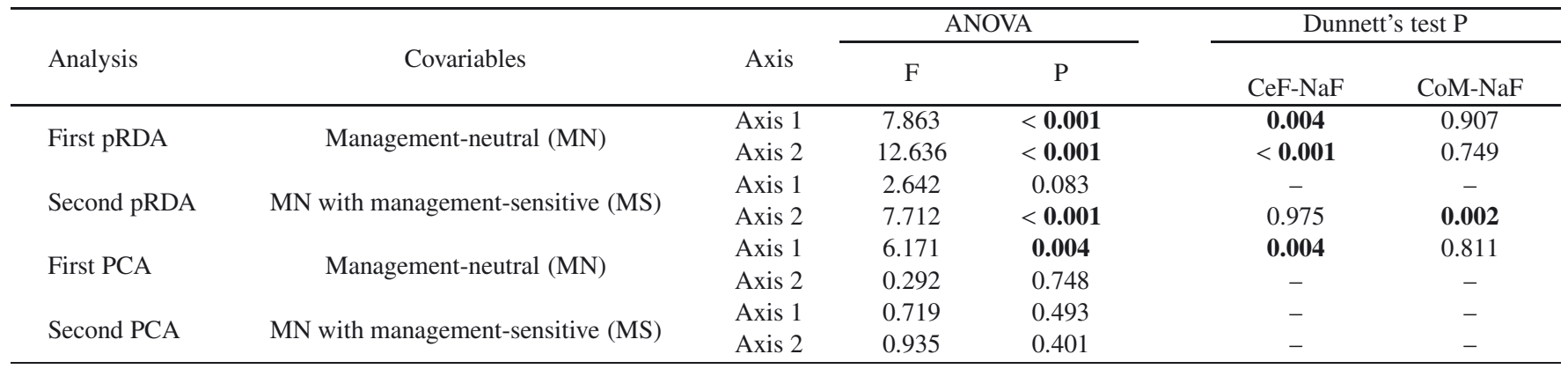

MS gap characteristics was factored out along with the MN gap characteristics in the second pRDA (Fig. 3), management type explained only $6.0 \%$ of the remaining variation in floristic composition. Thus, nearly half of the variation explained by management type was accounted for by the MS gap characteristics. Unlike in the first pRDA, the $\mathrm{CeF}$ and $\mathrm{NaF}$ gaps were more similar floristically (Euclidean distance 0.20 ) than the $\mathrm{CoM}$ and $\mathrm{NaF}$ gaps $(0.21)$. Thus, the difference in floristic similarity between the $\mathrm{CeF}$ and $\mathrm{NaF}$ gaps and the $\mathrm{CoM}$ and $\mathrm{NaF}$ gaps was explained by the effect of MS gap characteristics.

The two constrained axes of the second pRDA explained only $4.3 \%$ and $1.8 \%$ of the variation in floristic data, whereas the third and fourth unconstrained axes explained $7.7 \%$ and $5.8 \%$, demonstrating that important environmental gradients remained outside the analysis, despite controlling for the effect of MS gap characteristics. Along the first axis, the sample scores were not related to management type, whereas along the second axis they were (Tab. III). Dunnett's tests revealed that on the second axis, the difference between the CoM and $\mathrm{NaF}$ gaps was statistically significant, whereas that between the $\mathrm{CeF}$ and $\mathrm{NaF}$ gaps was not (Tab. III). According to the results of PCA, when the MS gap characteristics were added to the set of covariables, the differences between management types were not significant on either axis (Tab. III), confirming that MS variables explained the variation along management type.

\subsection{Distribution of taxa}

Altogether, we recorded 4176 individuals of the 52 taxa in the 46 gaps studied. The highest number of taxa was found in the NaF gaps (mean with SD $18.8 \pm 5.8$ ), followed by those in the CoM $(15.5 \pm 6.4)$ and the $\mathrm{CeF}(14.1 \pm 5.3)$. The differences in taxa richness were almost statistically significant (ANOVA; $F=3.082, P=0.056)$. The highest density of recorded taxa was found in the CeF gaps (111.3 \pm 55.1 individuals per gap), 


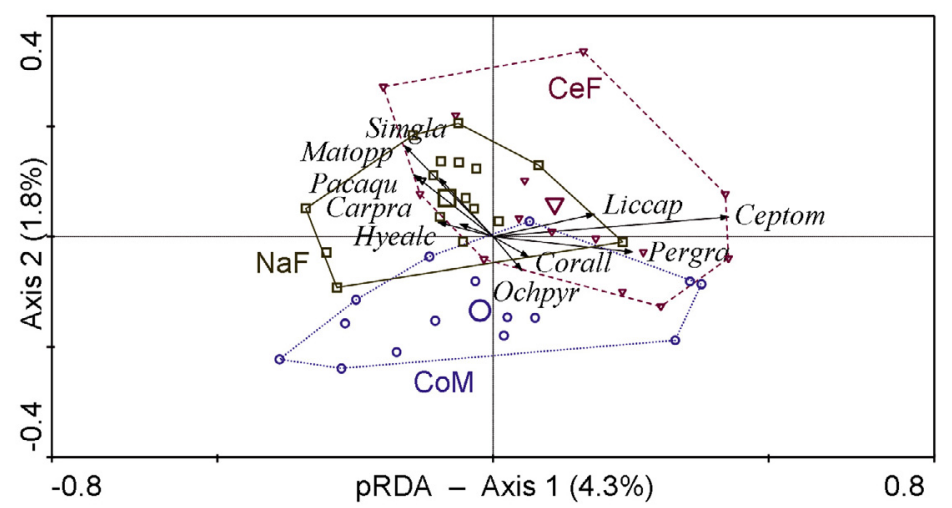

Figure 3. Partial redundancy analysis (pRDA) ordination diagram, plotting sample (gap) scores (small symbols) and class centroids of forest management types (large symbols) along with 10 taxa having the best fit. Distances between sample scores and between centroids correspond to Euclidean distances. Envelopes are drawn around samples of each management type, with sample scores represented as symbols $(\mathrm{CeF}=$ down triangle, $\mathrm{CoM}=$ circle, $\mathrm{NaF}=$ square). Axes 1 and 2 are constrained: management type is used as the explanatory variable. The percentage of variance in the floristic dataset (52 taxa) explained by each axis is indicated in brackets. Management-neutral (MN) gap characteristics as well as management-sensitive (MS) gap characteristics are used as covariables.

followed by the $\mathrm{NaF}(84.4 \pm 28.2)$ and $\mathrm{CoM}$ gaps $(77.1 \pm 57.2)$. The differences in density were not significant (ANOVA; $F=$ 2.091, $P=0.136)$.

Figure 2 presents the 10 taxa with the best fit, i.e. highest percentage of variability in abundance explained by management type. Cephaelis Sw. sp. (=Psychotria L. sp) was most strongly associated with the CeF gaps; $26.9 \%$ of the variation in Cephaelis abundance was explained by the two constrained axes. In order of increasing length of the projecting species arrow to the CeF centroid, the species associated with $\mathrm{CeF}$ gaps included Cephaelis tomentosa (Aubl.) Vahl (=Psychotria poeppigiana Müll. Arg.) (38.8\% of the variation explained), Licaria capitata (Schltdl. \& Cham.) Kosterm. (19.3\%), Perymenium grande Hemsl. (19.5\%) and Cordia alliodora (Ruiz \& Pav.) Oken (15.8\%). The CeF gaps were characterized by the highest stem density, highest coverage of young and canopy trees, and lowest coverage of litter, lianas and shrubs (Fig. 2). Density was strongly correlated $(r=0.69)$ with Axis 1 , which separated $\mathrm{CeF}$ from the other management types.

Mortoniodendron vestitum Lundell (12.3\%) was most strongly associated with the CoM gaps, followed by Ochroma pyramidale (Cav. ex Lam.) Urb. (14.2\%) (Fig. 3). The CoM sites were separated from the other management types along Axis 2, which correlated negatively with the coverage of shrubs $(r=-0.21)$ and litter $(r=-0.16)$ (Fig. 3).

The NaF gaps were generally characterized by a higher number of associated species compared to $\mathrm{CeF}$ or CoM gaps. The species with the strongest association with the $\mathrm{NaF}$ gaps was Simarouba glauca DC. (17.1\%), followed by Vismia baccifera (L.) Triana and Planch. (17.3\%), and Piper auritum Kunth (13.6\%). In addition, typical NaF taxa included Matayba oppositifolia (A. Rich) Britton (10.6\%), Virola koschnyi Warb. (10.8\%) and Garcinia intermedia (Pittier) Hammel (10.5\%). Liana coverage was highest in the NaF gaps, while the overall stem density was lowest (Fig. 3).

The second pRDA (Fig. 3) illustrates that when factoring out the effect of MS gap characteristics, the set of typi- cal species for $\mathrm{CeF}, \mathrm{NaF}$ and $\mathrm{CoM}$ gaps were little changed. The fit of species generally decreased, showing that MS gap characteristics explained part of the variation in species abundances. The greatest change was observed in Cephaelis: in the second pRDA, the two constrained axes explained only $2.8 \%$ of the variation in its abundance.

\section{DISCUSSION}

Contrary to our expectation, the similarity between the $\mathrm{CeF}$ and $\mathrm{NaF}$ gaps was lower than that between the $\mathrm{CoM}$ and $\mathrm{NaF}$ gaps. Furthermore, the low floristic similarity between the $\mathrm{CeF}$ and $\mathrm{NaF}$ gaps was explained when accounting for the effect of MS gap characteristics (Fig. 3; Tab. III), indicating that the $\mathrm{CeF}$ gap conditions were not as favourable for a natural forest composition as the gap conditions in the CoMs. These results suggest that the requirements in $\mathrm{CeF}$ management have not helped in minimizing the negative impact of logging on primary forest species. However, since there were a variety of uncontrolled factors involved in the study, this conclusion does not seem inevitable. Below we suggest three factors that may explain the low similarity between the $\mathrm{NaFs}$ and $\mathrm{CeFs}$ studied.

First, the results may not be directly linked to the current forest management system, but rather reflect past disturbance, which may have been higher in the CeFs than in the CoMs. The clearest difference in MS gap characteristics among the $\mathrm{CeFs}$, CoMs and NaFs was the high density of stems $\geq 1 \mathrm{~cm}$ in $\mathrm{dbh}$ in the CeFs (Fig. 3). This was due to a high abundance of pioneer species such as Cephaelis sp. and C. tomentosa in the $\mathrm{CeF}$ gaps. The predominance of light-demanding taxa may be related to structural changes in the forest, resulting from earlier loggings (Bermúdez et al., 2007; Kessler et al., 2005) or from hurricane disturbance (Brokaw and Grear, 1991; Crow, 1980).

Even when the floristic composition in $\mathrm{CeFs}$ indicated higher past disturbance, characteristics such as the higher coverage of young and canopy trees in the CeF gaps appeared to indicate reduced levels of logging damage compared 
with the CoM gaps (as also noted in Kukkonen et al., 2008). This suggests that the increased density of pioneer species may have resulted from disturbance that occurred before certified management practices were initiated. Earlier studies (e.g. Chapman and Chapman, 1997; Primack and Lee, 1991; Sist et al., 2003) have demonstrated that the structural changes caused by selective logging may persist for several decades.

In Río Cangrejal, the first certificate was granted only 12 y ago and during the first years after certification, the criteria were not strictly implemented (Markopoulos, 1999). In an ecological context, the time period may thus have been too short to observe the impacts of improved management practices on floristic composition. The higher similarity between the CoM and $\mathrm{NaF}$ gaps may be due to the CeFs having been logged more intensively during past decades and/or for a longer period of time than the CoMs. Certificates of sustainable forest management tend to be granted for such communities that have relatively long histories of commercial forest management (A. Nygren, 2007, pers. comm.). Without available information on the distribution of hurricane damage, we suggest that the CeFs may have been relatively more affected than the $\mathrm{CoMs}$ and NaFs, due to their higher mean altitude (Tab. I) (see Brokaw and Grear, 1991).

Second, seed dispersal from agropastoral areas may contribute to the low floristic similarity between the $\mathrm{CeF}$ and $\mathrm{NaF}$ gaps. Characteristic NaF taxa included typical primary forest species, with canopy trees such as S. glauca and M. oppositifolia (Cordero and Boshier, 2004; Hartshorn and Poveda, 1991), and typical shade-tolerant species such as $V$. koschnyi (Balderrama and Chazdon, 2005) and G. intermedia (Martínez-Garza, 2003). The floristic composition of the CoM gaps was similar to that of the $\mathrm{NaF}$ gaps (Fig. 3), whereas the typical taxa of the CeFs included secondary forest or fallow species. Cephaelis tomentosa thrives in open and disturbed areas and is rarely found under closed forest canopies (Hartshorn and Poveda, 1991). Perymenium grande is a secondary forest tree species that typically grows in open areas (Cordero and Boshier, 2004) and is abundant in fallows (Kass and Somarriba, 1999).

Earlier studies show that recovery of the natural tree species composition after selective logging is largely dependent on the proximity of undisturbed forest areas (cf. Chazdon, 2003). The CeFs of Río Cangrejal are generally located further from Pico Bonito National Park than the CoMs, of which only one is not located in the park's vicinity (Fig. 1). Thus, the CoMs may be relatively more influenced by seed dispersal from the NaFs, whereas in the CeFs, agropastoral and secondary forest species seem to be replacing forest species in the logging gaps. Differences in seed dispersal patterns may also affect species composition; many seed-dispersing animals avoid crossing open areas (Holl, 1999), whereas small wind-dispersed seeds of tree and shrub species that predominated in the CeFs may spread more randomly (Dalling et al., 2002).

Third, the ordination results indicated that a considerable amount of the variation in the floristic data remained unexplained. This suggests that we failed to include some major environmental gradients in the set of MN gap characteristics. In recording the distance between the forests as an $\mathrm{MN}$ variable, we probably captured only part of the variation related to the abiotic and biotic factors affecting floristic composition. In particular, soil factors such as fertility, drainage and texture are important determinants of tree species composition in tropical forests (Clark et al., 1999; de Carvalho et al., 2000).

Furthermore, besides above-ground competition for light, below-ground competition for nutrients by lianas (Schnitzer et al., 2005) or surrounding adult trees (Lewis and Tanner, 2000) may limit the survival of some tree species, especially in nutrient-poor soils. Although liana abundance tends to increase with logging intensity (Schnitzer et al., 2004), we observed a lower abundance of lianas in both $\mathrm{CeFs}$ and CoMs compared to NaFs. This was most likely due to liana cutting, which is commonly practiced in Río Cangrejal to reduce logging damage (Gerwing and Uhl, 2002). In community-based forest management systems, the differences between $\mathrm{CeF}$ and CoM management may in general be relatively small compared to large-scale industrial loggings. Because heavy machinery is not used and logging roads are few, such RIL practices as limiting skid rail damage and road construction do not apply.

\section{CONCLUSION}

One of the main aims of forest certification is to minimize the negative impacts of logging on the natural floristic composition. However, we found a lower floristic similarity between the CeFs and NaFs than between the CoMs and NaFs in the treefall gaps studied in northern Honduras. Based on the high abundance of pioneer species and gap environmental variables indicating reduced disturbance in the $\mathrm{CeFs}$, we suggest that factors such as past loggings, hurricanes and the location of the forests in relation to seed sources may have a greater impact on forest structure than implementing certified management practices. Therefore, landscape-level planning and restoration of degraded forest species may be important means for more efficient mitigation of the negative impacts of selective logging on forest structure. We recommend that such factors should be considered when planning guidelines for certifying community-based forest operations in the tropics.

\begin{abstract}
Acknowledgements: We wish to thank all the people in Río Cangrejal, especially our many field assistants, for making this study possible. For assistance in planning and conducting the fieldwork, we thank Reynel Rivera and Cecilia Käld. Taxonomic identification was performed by José Linares at the Paul C. Standley Herbarium (EAP) in Zamorano, Honduras. George Pilz from Zamorano and Jens Bittner from ESNACIFOR helped us in many ways. Hannu Rita, Anja Nygren, Jouko Rikkinen and two anonymous reviewers provided very valuable comments on the manuscript. This work was funded by the Academy of Finland (grant numbers 1205668 and 1107665) and the University of Helsinki.
\end{abstract}

\section{REFERENCES}

Balderrama S.I.V. and Chazdon R.L., 2005. Light-dependent seedling survival and growth of four tree species in Costa Rican secondgrowth rain forests. J. Trop. Ecol. 21: 383-395. 
Bermúdez A.M., Fernández-Palacios J.M., González-Mancebo J.M., Patiño J., Arévalo J.R., Otto R., and Delgado J.D., 2007. Floristic and structural recovery of a laurel forest community after clear-cutting: A 60 years chronosequence on La Palma (Canary Islands). Ann. For. Sci. 64: 109-119.

Brokaw N.V.L. and Grear J.S., 1991. Forest structure before and after hurricane Hugo at three elevations in the Luquillo Mountains, Puerto Rico. Biotropica 23: 386-392.

Carvalho de L.M.T., Fontes M.A.L., and Oliveira-Filho de A.T., 2000. Tree species distribution in canopy gaps and mature forest in an area of cloud forest of the Ibitipoca Range, south-eastern Brazil. Plant Ecol. 149: 9-22.

Chapman C.A. and Chapman L.J., 1997. Forest regeneration in logged and unlogged forests of Kibale National Park, Uganda. Biotropica 29: $396-412$.

Chazdon R.L., 2003. Tropical forest recovery: legacies of human impact and natural disturbances. Perspect. Plant Ecol. 6: 51-71.

Clark D.B., Palmer M.W., and Clark D.A., 1999. Edaphic factors and the landscape-scale distributions of tropical rain forest trees. Ecology 80 : 2662-2675.

Cordero J. and Boshier D.H., 2004. Simarouba glauca DC. In: Cordero J. and Boshier D.H. (Eds.), Árboles de Centroamérica, CATIE, Oxford Forestry Institute, FRP, Oxford, UK, pp. 879-882.

Crow T.R., 1980. A rainforest chronicle: a 30-year record of change in structure and composition at El Verde, Puerto Rico. Biotropica 12: $42-55$.

Cusack D. and Montagnini F., 2004. The role of native species plantations in recovery of understory woody diversity in degraded pasturelands of Costa Rica. For. Ecol. Manage. 188: 1-15.

Dalling J.W., Muller-Landau H.C., Wright S.J., and Hubbell S.P., 2002. Role of dispersal in the recruitment limitation of neotropical pioneer species. J. Ecol. 90: 714-727.

Denslow J.S., Schultz J.C., Vitousek P.M., and Strain B.R., 1990. Growth responses of tropical shrubs to treefall gap environments. Ecology 71: $165-179$.

Dickinson M.B., Whigham D.F., and Hermann S.M., 2000. Tree regeneration in felling and natural treefall disturbances in a semideciduous tropical forest in Mexico. For. Ecol. Manage. 134: 137-151.

Ferrando O.J.J., 1998. Composición y estructura del bosque latifoliado de la Costa Norte de Honduras: pautas ecológicas para su manejo. Master's Thesis. CATIE, Turrialba, Costa Rica, 71 p.

FSC (Forest Stewardship Council), 2004. Principles and Criteria for Forest Stewardship, Bonn, Germany.

Gerwing J.J. and Uhl C., 2002. Pre-logging liana cutting reduces liana regeneration in logging gaps in the eastern Brazilian Amazon. Ecol. Appl. 12: 1642-1651.

Hartshorn G.S. and Poveda L.J., 1991. Lista de especies arborescentes. In: Janzen D.H. (Ed.), Historia natural de Costa Rica, Editorial de la Universidad de Costa Rica, San José, Costa Rica, pp. 160-186.

Holdridge L.R., 1967. Life zone ecology, Tropical Science Center, San José, Costa Rica, 206 p.

Holl K.D., 1999. Factors limiting tropical rain forest regeneration in abandoned pasture: seed rain, seed germination, microclimate, and soil. Biotropica 31: 229-242.

Jackson S.M., Fredericksen T.S., and Malcolm J.R., 2002. Area disturbed and residual stand damage following logging in a Bolivian tropical forest. For. Ecol. Manage. 166: 271-283.

Kass D.C.L. and Somarriba E., 1999. Traditional fallows in Latin America. Agrofor. Syst. 47: 13-36.

Kessler M., Kessler P.J.A., Gradstein S.R., Bach K., Schmull M., and Pitopang R., 2005. Tree diversity in primary forest and different land use systems in Central Sulawesi, Indonesia. Biodivers. Conserv. 14: $547-560$.
Kukkonen M., Rita H., Hohnwald S., and Nygren A., 2008. Treefall gaps of certified, conventionally managed and natural forests as regeneration sites for neotropical timber trees in northern Honduras. For. Ecol. Manage. 255: 2163-2176.

Lepš J. and Šmilauer P., 2003. Multivariate Analysis of Ecological Data Using CANOCO, Cambridge University Press, Cambridge, UK, $269 \mathrm{p}$.

Lewis S.L. and Tanner E.V.J., 2000. Effects of above- and belowground competition on growth and survival of rain forest tree seedlings. Ecology 81: 2525-2538.

Markopoulos M.D., 1999. The impacts of certification on campesino forestry groups in northern Honduras, Oxford Forestry Institute, Oxford, UK, $56 \mathrm{p}$.

Martínez-Garza C., 2003. Selecting late-successional trees for tropical forest restoration, PhD Thesis, University of Illinois, Chicago, USA, $146 \mathrm{p}$.

Pereira R.J., Zweede J.C., Asner G.P., and Keller M., 2002. Forest canopy damage and recovery in reduced-impact and conventional selective logging in eastern Para, Brazil. For. Ecol. Manage. 168: 77-89.

Primack R.B. and Lee H.S., 1991. Population dynamics of pioneer (Macaranga) trees and understorey (Mallotus) trees (Euphorbiaceae) in primary and selectively logged Bornean rain forests. J. Trop. Ecol. 7: 439-457.

Salazar R.B., 2000. Efectos del aprovechamiento forestal en la riqueza, diversidad y composición florística de un bosque húmedo en la costa norte de Honduras. Master's Thesis. CATIE, Turrialba, Costa Rica. $90 \mathrm{p}$.

Schnitzer S.A. and Bongers F., 2002. The ecology of lianas and their role in forests. Trends Ecol. Evol. 17: 223-230.

Schnitzer S.A., Parren M.P.E., and Bongers F., 2004. Recruitment of lianas into logging gaps and the effects of pre-harvest climber cutting in a lowland forest in Cameroon. For. Ecol. Manage. 190: 87-98.

Schnitzer S.A., Kuzee M.E., and Bongers F., 2005. Disentangling aboveand below-ground competition between lianas and trees in a tropical forest. J. Ecol. 93: 1115-1125.

Sist P., Nolan T., Bertault J.-G., and Dykstra D., 1998. Harvesting intensity versus sustainability in Indonesia. For. Ecol. Manage. 108: 251-260.

Sist P., Picard N., and Gourlet-Fleury S., 2003. Sustainable cutting cycle and yields in a lowland mixed dipterocarp forest of Borneo. Ann. For. Sci. 60: 803-814.

Sist P., Sheil D., Kartawinata K., and Priyadi H., 2003. Reduced-impact logging in Indonesian Borneo: some results confirming the need for new silvicultural prescriptions. For. Ecol. Manage. 179: 415-427.

SPSS Inc., 2007. SPSS for Windows, version 16.0, release 16.0.1., Chicago, USA.

Ter Braak C.J.F. and Šmilauer P., 2002. CANOCO reference manual and CanoDraw for Windows user's guide: Software for Canonical Community Ordination (version 4.5), Microcomputer Power, Ithaca, NY, USA, $500 \mathrm{p}$.

Ter Braak C.J.F. and Šmilauer P., 2006. CANOCO for Windows, Biometrix - Plant Research International, Wageningen, The Netherlands.

Uhl C. and Vieira I.C.G., 1989. Ecological impacts of selective logging in the Brazilian Amazon: a case study from the Paragominas region of the state of Pará. Biotropica 21: 98-106.

UNECE (United Nations Economic Commission for Europe)/FAO (Food and Agriculture Organization of the United Nations), 2008. Forest Products Annual Market Review 2007-2008, United Nations, New York and Geneva, $153 \mathrm{p}$.

Van Kooten C.G., Nelson H.W., and Vertinsky I., 2005. Certification of sustainable forest management practices: a global perspective on why countries certify. Forest Policy Economy 7: 857-867. 